\title{
El estoicismo como moral en Vives, el Brocense y Quevedo
}

\author{
David DOMÍNGUEZ MANZANO \\ UCM \\ (ddmanzano88@gmail.com)
}

\begin{abstract}
RESUMEN
En este artículo nos proponemos abordar algunas de las formas más paradigmáticas en que el estoicismo antiguo fue reconstruido y adoptado como filosofía moral cristiana durante los siglos XVI y XVII. Con este propósito, hemos centrado nuestra atención en tres autores españoles: Luis Vives, Francisco Sánchez de las Brozas y Francisco de Quevedo. A través del comentario de algunas de sus obras, esperamos poder mostrar cómo la Contrarreforma y la disolución de las esperanzas del humanismo cristiano propiciaron un cambio en la interpretación de la doctrina estoica acerca del juicio moral y su transformación, ya en el período Barroco, en una doctrina del desengaño
\end{abstract}

PALABRAS CLAVE: Estoicismo; Humanismo; Contrarreforma; Conocimiento Propio; Desengaño

\begin{abstract}
In this article we attempt to approach some of the most paradigmatic forms in which ancient stoicism was reconstructed and adopted as a Christian moral philosophy during the $16^{\text {th }}$ and $17^{\text {th }}$ centuries. For this purpose, we have focused on the work of three Spanish authors: Luis Vives, Francisco Sánchez de las Brozas and Francisco de Quevedo. By commenting some of their writings, we expect to be able to illustrate how the Counter-Reformation and the dissolution of the hopes of the Christian humanists led to a change in the interpretation of the stoic doctrine of moral judgment and its subsequent transformation, during the Baroque period, into a doctrine of disillusionment
\end{abstract}

KEY WORDS: Stoicism; Humanism; CounterReformation; Self-knowledge; Disillusionment

\section{Introducción: la singularidad del movimiento neoestoico}

Dentro de la ya larga historia del cristianismo, no cabe duda de que las últimas décadas del siglo XVI constituyen un período de especial turbulencia. Mientras una gran parte de la Europa continental padecía los estragos de las guerras intestinas entre católicos y protestantes, la España de Felipe II, por vía del tribunal de la Santa Inquisición, se afanaba en imponer a sangre y fuego la nueva ortodoxia tridentina en su territorio cortando de raíz todo posible conato de herejía en suelo peninsular. Tanto a un lado como a otro de los Pirineos, la situación política y social dejó inevitablemente su huella en los ambientes intelectuales, que paulatinamente fueron abandonando el optimismo característico de épocas precedentes y adaptándose a unas nuevas circunstancias que, en el caso específico de España, pasaban por un recrudecimiento de la censura y por la desaparición del mercado de obras como las de Erasmo de Rotterdam, que habían constituido un importante revulsivo para la vida espiritual durante la primera mitad del siglo y que se hallaban ahora entre las incluidas en el Index Libri Probibitorum. A medida que arreciaban las cautelas, y 
autores que quizás en otro momento no hubieran dudado en emplear en sus escritos un tono más abierto y polémico se veían obligados a disimular sus ideas bajo el manto de un lenguaje forzosamente elíptico, la atmósfera de efervescencia intelectual que había distinguido a la etapa renacentista empezó a decaer irremediablemente. Las ansias de renovación de los humanistas cristianos se vieron frustradas ante la ferocidad tanto de la Reforma, tal y como ésta se llevó efectivamente a cabo, como de la Contrarreforma que más tarde se implantó en los países católicos. La esperanza y la confianza en el futuro no tuvieron más remedio que dejar paso al desencanto y la incertidumbre.

En una coyuntura semejante, en la que, como decía Montaigne, cualquiera «se encuentra a punto de sufrir un vuelco completo de fortuna» ${ }^{1}$ y el desconcierto se extendía a todos los niveles de la existencia, no es de extrañar que se produjese, estrechamente unido al afloramiento de posiciones escépticas, un renovado interés por la moral estoica. Y es que «la filosofía estoica contenía una ética a propósito para dominar los golpes más duros de la vida, y que además tenía la ventaja de ser capaz de dar un fundamento a todos los cristianos, de cualquier confesión que fueran, por encima de las dificultades dogmáticas. La Stoa enseñaba una moral de tipo interior estrictísima, que en puntos decisivos estaba de acuerdo con los fundamentos del credo cristiano» ${ }^{2}$.

Obras como el De constantia, la Manuductio ad Stoicam philosophiam o la Physiologia Stoicorum del flamenco Justo Lipsio (1547-1606) o La Philosophie morale des Estoiques y De la constance et consolation ès calamités publiques del francés Guillaume du Vair (1556-1621) contribuyeron a la forja de toda una corriente de pensamiento moral, que gozó de gran difusión y causó un importante impacto a finales del siglo XVI y principios del XVII, y que pasado el tiempo ha recibido la denominación de neoestoicismo. Lo que en tales obras se buscaba, fundamentalmente, era la construcción de un sistema moral autónomo, justificable por sí mismo e independiente de imposiciones doctrinarias externas, pero que no dejase, sin embargo, de ser compatible con los dogmas fundamentales del cristianismo; de ahí, por tanto, el recurso a las ideas morales de la Stoa más tardía —más específicamente

\footnotetext{
${ }^{1}$ Michel de MONTAIGNE, Ensayos, Barcelona, Acantilado, 2007, III, 12, 1561.

${ }^{2}$ Karl Alfred BLÜHER, Séneca en España. Investigaciones sobre la Recepción de Séneca en España desde el siglo XIII hasta el siglo XVII, Madrid, Gredos, 1983, 391.
} 
a las de Séneca y Epicteto, grandes referentes, respectivamente, de Lipsio y de du Vair-, cuyas analogías con la moralidad cristiana habían venido siendo señaladas ya desde la época de los Padres de la Iglesia.

El ideario de la escuela del pórtico convenía en grado sumo a las exigencias de una época como aquella. Por extraños y sorprendentes que nos puedan parecer, los intentos de Lipsio por armonizar la doctrina estoica del fatum con la defensa cristiana del libre albedrío responden en verdad a una necesidad subyacente de buscar consuelo ante las adversidades de la vida, que es justamente lo que le empuja a una actitud de sumisión ante los designios inexpugnables de la providencia ${ }^{3}$. La imperturbabilidad ante los acontecimientos externos es el gran beneficio que se esperaba conseguir mediante la adhesión a una ética de observancia puramente interna y que no consigna acciones de ningún tipo, sino que cifra la consecución de la virtud en el libre rechazo de los bienes exteriores y en la aceptación del destino. No en vano, «constancia» y «fortaleza» son dos palabras que los neoestoicos repetirían hasta la saciedad, y actitudes que no se cansarían de prescribir como los únicos remedios posibles ante los males que traía el siglo. Los esfuerzos puestos en su consecución tendrían su contrapartida en una desvalorización del mundo sensible, concomitante al escepticismo que imperaba en aquel momento y emblemático de la desconfianza ante una realidad que se había vuelto inhóspita 4 .

Siendo el neoestoicismo como fue, en definitiva, un producto cultural propio de un período de crisis, no deja de ser cierto también que su emergencia tuvo lugar en un momento clave en el desarrollo de la historia de las ideas en Europa, en el cual situamos la transición del Renacimiento a la Modernidad. Semejante circunstancia no es del todo trivial, pues podemos identificar en el neoestoicismo, si

\footnotetext{
3 Para las doctrinas neoestoicas de Lipsio, cfr., Karl Alfred BLÜHER, Séneca en España, op. cit., 393 y ss.

${ }^{4}$ Esta desvalorización de lo terrenal vendría mediada, en Lipsio y en otros, por una lectura «racionalista» de la doctrina estoica del juicio. Para los estoicos el cometido del juicio consistía en examinar las representaciones provisionales ( $\varphi \alpha v \tau \alpha \sigma i ́ \alpha$ ) que llegaban a la mente y, a la luz de los conceptos morales presentes en ella, ofrecerles o denegarles su asentimiento antes de proceder a su

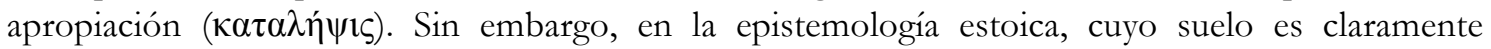
empirista, los conceptos morales se derivan directamente de anticipaciones ( $\pi \rho 0 \lambda \eta \dot{\psi} \psi \varepsilon 1 \varsigma)$ de origen sensible. En Lipsio, en cambio, no hay apelación alguna a lo empírico en la conformación de los conceptos morales, cuya fuente sería el alma misma. Esto, entre otras cosas, nos hace comprensibles dos características peculiares del neoestoicismo que lo distinguen de la Stoa antigua: su hiperbolización de la autonomía racional de la mente humana y su connivencia con el escepticismo (Cfr., BLÜHER, Séneca en España, op. cit., 398-399).
} 
no a un movimiento que fue agente efectivo de dicha transición, sí al menos a uno cuyos rasgos más llamativos son claramente sintomáticos de que se estaba produciendo un cambio. El resurgimiento de corrientes helenísticas como el escepticismo, el epicureísmo y el estoicismo en los últimos años del siglo XVI y los primeros del XVII fue cómplice de un nuevo interés, aparecido en el seno del humanismo declinante, por distinguir netamente los ámbitos de la razón y de la fe, contribuyendo así a la forja tanto de un nuevo modelo de racionalidad como de un nuevo fideísmo que, a la larga, serían decisivos para el desarrollo de la ciencia y la filosofía modernas. En este orden de cosas, la importancia del neoestoicismo residiría en haber pergeñado, por primera vez, un sistema de moral racional autónomo e independiente de la teología, sentando las bases para ulteriores intentos en este sentido a lo largo de la Modernidad 5 .

Sin embargo, el neoestoicismo no fue simplemente un eslabón más en la cadena de racionalizaciones y secularizaciones que darían paso a la era moderna. La transformación del humanismo en neoestoicismo (o, si se prefiere, la sustitución del primero por el segundo) no supuso tan sólo ni principalmente un paso adelante hacia una ética secularizada; es más, ni siquiera puede decirse que fuera así en todos los casos, pues el tardío neoestoicismo español se caracterizó precisamente por hallar perfecto acomodo en el marco religioso de la Contrarreforma. No hay que perder de vista que uno de los rasgos que quizás mejor distinguen al neoestoicismo, y que resulta especialmente patente en su vertiente española, es el hecho de que fue uno de los primeros movimientos intelectuales en detentar una imagen del individuo y de su relación con el mundo perfectamente afín a la nueva atmósfera espiritual que empezaba ya a gestarse en los albores del siglo XVII y cuyas señas de identidad connota, mucho más sutilmente que el término «Modernidad», la palabra «Barroco». Si examinamos las obras morales de un autor como Quevedo, es fácil comprobar que la aceptación de la filosofía estoica que tiene lugar en ellas, lejos de repercutir en

\footnotetext{
${ }^{5}$ Estudiar la incidencia del neoestoicismo en el desarrollo de las ciencias y de la filosofía sistemática del siglo XVII no es el objetivo que nos proponemos en este artículo. Sin embargo, no nos resistimos a llamar la atención sobre las raíces estoicas de las tres máximas que componen la moral provisional expuesta por Descartes en la tercera parte del Discurso del método: sumisión a las leyes y costumbres del país y a la religión; firmeza en las acciones y constancia en las opiniones; y, sobre todo, «procurar siempre vencerme a mí mismo antes que a la fortuna y alterar mis deseos antes que el orden del mundo; y acostumbrarme a creer que sólo nuestros pensamientos están enteramente en nuestro poder» (Cfr., René DESCARTES, A.T., VI, 22-31).
} 
la construcción de una ética racional autónoma, lo que hace en verdad es contribuir a la cimentación de esa moral del desengaño, tan propia del siglo de Oro, y en la que algunos han querido ver una de las expresiones más características del espíritu español.

Nuestra percepción de la complejidad y la polivalencia del papel jugado por la ética estoica en las transformaciones culturales acaecidas entre los siglos XVI y XVII se avivará más todavía si tenemos en cuenta que en el movimiento intelectual que antecedió directamente al neoestoicismo, el humanismo cristiano, también ensayó en algunos momentos un acercamiento a las doctrinas de la Stoa, si bien con intenciones y motivaciones muy distintas a las que ostentarían sus sucesores. Es indudable, por tanto, que la recepción y aceptación de la moral estoica padeció, durante aquellos tiempos, sucesivos cambios y readaptaciones, y que éstos debieron responder, a su vez, a las continuas mutaciones en el ambiente intelectual y espiritual de la época.

En las páginas que siguen procuraremos ofrecer una pequeña panorámica de los avatares de la recepción del estoicismo desde la nueva aceptación que el humanismo erasmiano le confiere hasta su posterior inserción en la moral de la Contrarreforma. Para ello, procederemos a un breve examen de la obra de tres autores españoles: el humanista Juan Luis Vives y los neoestoicos Francisco Sánchez de las Brozas y Francisco de Quevedo. La comparación entre sus respectivas formulaciones morales nos servirá para arrojar luz tanto sobre las líneas de continuidad en la historia de la recepción del estoicismo como sobre sus puntos de inflexión; nos servirá también, por extensión, para adquirir una percepción más profunda de aquellos elementos que, desde el ambiente espiritual del Renacimiento, consiguen penetrar en el Barroco, así como sobre aquellos otros que, siendo específicos y peculiares de cada época, nos abren una ventana al modo de sentir y de comprender el mundo que las caracterizan.

\section{1.- Humanismo y Philosophia Christi: elementos estoicos}

\section{1.- Erasmo y la Philosophia Christi: el giro a la interioridad}

La forma que tomó la recepción del estoicismo a lo largo del siglo XVI, e incluso el mismo surgimiento del neoestoicismo, serían incomprensibles sin la contribución 
que supuso la obra de Erasmo de Rotterdam (1466-1536). Contribución que no sólo se cifra (que también) en su monumental edición crítica de las obras de Séneca - la primera en desechar como apócrifos textos que habían gozado de cierta preponderancia durante el Medievo y en poner punto final a la leyenda de la amistad del filósofo cordobés con San Pablo—6 ${ }^{6}$, sino también y principalmente en haber sido el roterodamo el primero en profesar un nuevo tipo de espiritualidad religiosa, que al cabo de poco tiempo se extendería por gran parte de Europa y que recibiría el nombre de bumanismo cristiano. En qué sentido determina el surgimiento de esta espiritualidad la recepción posterior del estoicismo, intentaremos esbozarlo ahora.

El pensamiento erasmiano tiene como puntos de partida el desencanto producido por una religión al uso que, enredada en ritos y ceremonias, había perdido el sentido de la devoción y se había entregado a la superstición, y la indignación que suscitaba una teología como la escolástica que se había entregado a los encantos de la dialéctica dejando de lado el verdadero significado del cristianismo. Inspirado por el humanismo que había profesado desde joven y por la nueva piedad evangélica que le habían descubierto predicadores como John Colet o Jean Vitrier, Erasmo dirigirá toda su producción intelectual a la búsqueda de una renovación espiritual del cristianismo.

Dicha búsqueda encontrará una primera expresión programática en el Enchiridion militis christiani (1503), la obra de Erasmo que mayor difusión alcanzó en el siglo XVI. Este pequeño libro es un manual de cristianismo interior que se sustenta sobre la afirmación, repetida a lo largo de toda la obra, de que lo que caracteriza al buen cristiano es el seguimiento de la ley del espíritu, pues ésta y no otra es la ley de Cristo, y es mediante el espíritu que nos incorporamos a ese gran cuerpo que es la comunidad de los cristianos y cuya cabeza es el mismo Cristo. Ahora bien, si cumplimos con la exhortación, común al cristianismo y a las filosofías paganas, que nos insta a conocernos a nosotros mismos, descubriremos que el espíritu está en antagonismo con la carne, razón por la cual la vida del cristiano es una continua lucha contra aquellas fuerzas que intentan arruinar su parte espiritual e inmortal. En razón de ello, el cristiano deberá recurrir a la oración interior, y no apegarse a la materialidad de la letra; deberá también profesar el cristianismo con su

${ }^{6}$ Cfr., BLÜHER, Séneca en España, op. cit., 238 y ss. 
alma, y no limitarse a seguir supersticiosamente los ritos; deberá, por último, huir de los vicios y encaminarse a la virtud, pues la virtud es sabiduría ${ }^{7}$ y la sabiduría conduce a Cristo.

A grandes rasgos, la doctrina profesada por Erasmo en el Enchiridion se resume en estas ideas básicas que acabamos de consignar. Como se podrá comprobar, no hay en ellas apelación explícita alguna al estoicismo ${ }^{8}$. Y es que el Enchiridion no deja de ser un manual de religión práctica sustentado en una Philosophia Christi extraída del propio Nuevo Testamento y no remitida a fuentes paganas. Esta Philosophia Christi no es una mera moral cristiana, sino más bien un cristianismo que se descubre a sí mismo como seguimiento del ejemplo de Cristo y por tanto como moral. La de Erasmo es una religiosidad que, precisamente por estar incardinada en el espíritu pero estar, a la vez, en lucha con la carne, ha de tener necesariamente una orientación práctica, encaminada a la búsqueda de la virtud en tanto que esta es, no fin en sí mismo, sino medio para la felicidad y para el encuentro con Dios.

Sin embargo, esto no será óbice para que el Enchiridion siente las bases de todo futuro intento de reconstruir el estoicismo como sistema de moral autónoma. A este respecto, lo verdaderamente crucial de la obrita de Erasmo es la insistencia en el imperativo socrático del conocimiento de sí: mediante él, el roterodamo no sólo propicia el acercamiento entre cristianismo y sabiduría pagana, sino que abre la vía para una nueva comprensión del individuo y su relación con el mundo que no estará ya mediatizada por un marco metafísico-teológico previo, sino que tomará como punto de partida absoluto la reflexión sobre la propia interioridad orientada desde una perspectiva práctica: el individuo humano se reconoce así como compuesto por carne, alma y espíritu; descubrirá que en esta última parte de su propio yo reside su

\footnotetext{
7 «De la misma manera, la absoluta probidad en todos sus aspectos es llamada sapientia, sabiduría» (ERASMO de Rotterdam, Enquiridion, Madrid, B.A.C., 2001, cap.3, 85). O también: «Quiere San Pablo que seamos sabios para el bien y simples para el mal» (Ibid., cap.3, 87).

8 Las que quizás sean las alusiones más importantes a la filosofía pagana realizadas en el Enquiridion tienen lugar en el capítulo 2, donde Erasmo recomienda la lectura de los autores paganos como propedéutica para un estudio de las sagradas escrituras que vaya más allá de la mera letra y sea capaz de penetrar en el espíritu de las mismas; y en la séptima regla del capítulo 8 , donde se señala cómo los gentiles, aun careciendo de revelación y desconociendo la existencia del premio y el castigo divinos, sabían perfectamente que la virtud era deseable en sí misma por el solo contraste con la ignominia de los vicios (Cfr., ERASMO, Enquiridion, op. cit., 221). En general, los estoicos aparecen citados aquí y allá — por ejemplo, al inicio del capítulo 3 (Cfr., Ibíd., 85)- como «maestros de virtud».
} 
más alta dignidad, y se dedicará enfervorecidamente a cultivarla y preservarla9, pues de ella penden su libertad y su felicidad. La radical libertad e independencia del espíritu humano, su dignidad: éste es el gran descubrimiento de Erasmo, el pilar de su humanismo.

Como se verá, las nuevas coordenadas establecidas por Erasmo harán fácil la adhesión a una moral como la estoica que ponía todo su énfasis en la interioridad del individuo y que se atribuía como fin práctico último el cultivo de la virtud, entendida como mantenimiento de la tranquilidad del ánimo ante las pasiones, los vicios y los embates de la fortuna.

La Philosophia Christi de Erasmo había sido una moral evangélica fideísta en la medida en que, al fundar ésta en el conocimiento de sí, el roterodamo había empleado como base la antropología de San Pablo, Orígenes y San Agustín. Juan Luis Vives, quizás el más importante discípulo del humanista holandés, rebasaría en este punto las pretensiones de su maestro y fundaría el conocimiento propio, no ya en doctrinas evangélicas, sino en una epistemología racional que tomará prestada de los estoicos.

\section{2.- Fuentes estoicas del humanismo de Juan Luis Vives}

La obra de Juan Luis Vives (1492-1540) constituye un ejemplo muy significativo de la faceta más programática del humanismo cristiano y de la infatigable preocupación que el movimiento mostró por el problema de la educación. Su monumental trabajo De disciplinis, que propone una reforma de arriba abajo del sistema educativo imperante en la época - siempre con vistas a la imposición de un programa de formación cristiano-humanístico-, da buena cuenta de ello. Al igual que su maestro Erasmo, el humanista valenciano consideraba extremadamente deficiente -e incluso perjudicial- la enseñanza que ofrecían las escuelas universitarias, ya que en su empeño por adiestrar a sus alumnos en el uso de la dialéctica no sólo se olvidaban de instruirlos también en la bondad y la virtud, sino que además los corrompían proporcionándoles una herramienta para argumentar non pro bona causa, sed pro invicto. Por otro lado, la ética aristotélico-escolástica que se enseñaba en las facultades era, a ojos de Vives, un artificio meramente especulativo que no sólo

${ }^{9}$ Cfr., ERASMO, Enquiridion, op. cit., cap. 8, regla 18: "Grandeza de la dignidad humana". 
resultaba inaplicable en la práctica, sino que además era incompatible con el cristianismo en puntos tales como su afirmación de que la felicidad es adquirible a través de los bienes externos ${ }^{10}$. La crítica que emprende contra la concepción de la virtud como término medio entre dos vicios — crítica que, como veremos más adelante, también recoge Sánchez de las Brozas- constituye un ejemplo paradigmático de su preocupación fidedigna por la educación moral y de su firme convicción, arraigada en el erasmismo, de que para nada vale la erudición si ésta no se traduce en réditos para la vida práctica. $\mathrm{Y}$ es que si algo disgusta a Vives de aquella concepción no es otra cosa que su efectiva inoperancia propedéutica, pues ni ofrece una definición de la virtud exenta de ambigüedades ni proporciona clave alguna sobre cómo haya que alcanzarla.

La principal formulación de la ética humanístico-cristiana de Vives la encontramos en una pequeña obrita escrita en aforismos que lleva el título de Introductio ad Sapientiam ${ }^{11}$ (1524). En su defensa de una sabiduría práctica de corte interiorista, que toma como punto de partida el imperativo socrático del conocimiento de sí (\$11) y que se asigna como su último paso el conocimiento de Dios (\$592), el opúsculo de Vives se sitúa claramente en la línea abierta por el Enchiridion de Erasmo. Sin embargo, la propuesta vivesiana presentará aspectos novedosos en la medida en que, como ya avanzamos, tomará pie para su construcción en una teoría del juicio deudora de las tesis epistemológicas de la escuela estoica. Dicha teoría - que el valenciano desarrolla en mayor profundidad en obras como De anima et vita o De instrumento probabilitatis - vendría a sostener, en primer lugar, que el origen de los conceptos morales de «bueno»y «malo» se encuentra en la aplicación del juicio sobre ciertas «anticipaciones» que la naturaleza planta como «semillas» en el hombre, a las que deberá ofrecer o denegar su asentimiento $^{12}$. En segundo lugar, Vives situaría también en el juicio el origen de la

\footnotetext{
${ }^{10}$ Cfr., VIVES, Las disciplinas, Barcelona, Ed. Orbis, 1985, I vi, 1, 217 y ss. Vives arremete contra esta tesis haciendo uso de argumentos estoicos como el empleado por Séneca en Ep. ad Luc., 85.

${ }^{11}$ Nuestras citas estarán en todo momento referidas a Juan Luis VIVES, Introducción a la sabiduría; El Sabio, Madrid, Tecnos, 2010. Esta edición cifra en 592 los aforismos de la obra. Otras ediciones cuadran esta cifra en 600 , con lo cual la numeración puede variar con respecto a la que aquí ofrecemos.

12 Dado el giro racionalista y subjetivista que el neoestoicismo imprimirá a esta doctrina del juicio, es importante hacer notar ahora que, en su psicología, Vives no se separa de la concepción tradicional de la Stoa en lo que se refiere al origen sensible de estas «anticipaciones».
} 
conducta moral, en la medida en que es la valoración que mediante dicha facultad hacemos de las cosas lo que luego determina nuestra actitud con respecto a ellas. ${ }^{13}$

Esta doctrina del juicio entra en juego en la Introductio ad Sapientiam como pilar fundamental sobre el que se asienta el concepto de sabiduría. De este modo, ya en los dos primeros aforismos vemos entrar en juego un principio que fue fundamental para los estoicos ${ }^{14}$ :

\$1 La verdadera sabiduría consiste en juzgar rectamente de las cosas de modo que consideremos cada una tal cual es; no tomemos las viles por preciosas ni rechacemos las preciosas como viles; no vituperemos las dignas de alabanza ni elogiemos las merecedoras de vituperio.

$\$ 2$ En efecto, de aquí nace todo error en las mentes de los hombres y todo vicio; y no hay nada en la vida humana más detestable que esa depravación del juicio que no da a las cosas su justo valor.

Esta concepción de la sabiduría con que se abre la obra será lo que guíe el desarrollo vivesiano del conocimiento de sí. Así, tras dividir las cosas humanas en pertenecientes al alma, pertenecientes al cuerpo y externas al hombre (\$S12-16), Vives emprende el examen de cada una de ellas, juzgando su «naturaleza y valor». El resultado es análogo al obtenido por Erasmo y por los mismos estoicos: «La reina y la primera y más excelente de todas las cosas es la Virtud. Todas las demás, si quieren cumplir con su cometido, deben estar a su servicio» (\$17). Esta verdad primera, descubierta por el acto del juicio aplicado a la propia alma, presidirá la valorización del resto de las cosas, que en la Introductio ad sapientiam está plagada de resonancias estoicas. Es remisible al pensamiento de la Stoa, por ejemplo, la contraposición entre la sabiduría que juzga rectamente y las opiniones corrientes del vulgo (i.e. $\left.\int \$ 3,4,20,73\right)^{15}$. También encontramos presente en algunos aforismos (i.e. $\$ \$ 67,212,214)$ el gran tópico estoico — que jugará un importante papel, como veremos, en La cuna y la sepultura de Quevedo- según el cual la vida no nos pertenece, sino que la tenemos en préstamo. Concepción ésta que viene a redundar en la idea, que marca la tónica general del libro, de que nada tiene verdadero valor si no conlleva un cierto aprovechamiento del alma y, más concretamente, un

\footnotetext{
13 Para una exposición más detallada de las tesis de Vives en torno al iudicium, así como de su paralelismo con la teoría estoica del conocimiento, cfr. BLÜHER, Séneca en España, op. cit., 268-275.

${ }^{14}$ Cfr., SÉNECA, Ep. ad Luc., 89, 14.

15 Este tópico estaba ya también presente en Erasmo. Cfr., ERASMO, Enquiridion, op. cit., cap. 8, regla 6: "No hay que seguir la opinión de la gente, sino la de Cristo".
} 
acrecentamiento de la virtud. Vives recalcará, además, que sólo lo que concierne a nuestra alma está verdaderamente bajo nuestro control, y que por tanto sólo en ella reside nuestra libertad ${ }^{16}$. Siguiendo a Erasmo, no es la carne, sino el espíritu, lo que nos hace libres.

A grandes rasgos, la ética de Vives, al igual que la estoica, se funda sobre una base que podríamos calificar de «intelectualista»: considera que la conducta práctica, del mismo modo que el conocimiento teórico, toma pie en el juicio y asentimiento de la razón con respecto a aquellos objetos sobre los que ulteriormente habrán de tomarse las decisiones, adscribiéndoles, en vez de valor de «verdad» o «falsedad», valor de «bondad»o «maldad». Esta postura fue la que llevó a los estoicos a considerar no sólo deseable, sino totalmente posible que el hombre llegase a liberarse de las pasiones y los afectos sometiéndolos al juicio de la razón y sacando a la luz su verdadero valor. Vives, como buen cristiano, no puede desear la eliminación de afectos; sin embargo, de la Introductio ad sapientiam se colige un interés por encontrar un modo de dominarlos y someterlos a control racional, siempre con la mirada puesta en su aprovechamiento moral ${ }^{17}$.

Hemos de tener en cuenta que, aunque es patente y manifiesto que Vives adopta en su obra algunas doctrinas estoicas, les confiere no obstante un sentido y extrae un rédito de ellas que ni estaban estrictamente presentes en el estoicismo clásico ni serán mantenidos por el neoestoicismo posterior. En la obra de Vives, el enfoque individual y, digamos, «subjetivista» desde el que se afrontan los problemas éticos no anula en absoluto la perspectiva de la convivencia que en el humanismo, en tanto que movimiento universalista y pacifista, no deja nunca de estar presente. De todas las obras del valenciano, quizás sea en De concordia et discordia in bumano genere (1529) donde resulta más evidente la incardinación política y social de sus ideas

${ }^{16}$ Cfr. \$223 «Libre es aquel que desea sólo lo que está en su propia mano; el que no, es un esclavo». Esta misma tesis llegará, a través de Epicteto (Cfr. Encheiridion, I, 2), al pensamiento de Sánchez de las Brozas y de Quevedo.

17 Cfr. $\$ 120$ : «Este es el orden de la naturaleza: que la sabiduría lo gobierne todo, obedezcan al hombre las demás cosas que vemos; y en el hombre, el cuerpo obedezca al ánimo, el ánimo a la mente, la mente a Dios. Si uno transgrede este orden, peca». De aquí se desprende que el alma debe dominar sobre las pasiones, pero no que éstas deban ser eliminadas. Así, dos aforismos más adelante: «Por eso nuestra mente está dotada de la potencia intelectiva, para poder juzgar cada cosa y saber qué actos son buenos y hacerlos y cuáles son malos y evitarlos; y también de una fuerza de voluntad soberana, para que no haya nada en el ánimo que no obedezca a su imperio, si ella se empeña, ni ceda nada de su derecho» (\$122). 
educativas y morales. Sostiene allí Vives que el germen de la discordia y de los conflictos no es otro que el estallido incontrolado de las pasiones; por el contrario, la garantía de la concordia y de la convivencia social pacífica se halla justamente en el gobierno racional de las pasiones, para cuya consecución sólo existe una vía: educar a los individuos en la virtud ${ }^{18}$. En lo que respecta a la formación ética, Vives no pondrá el acento en el resguardo de la tranquilidad del ánimo de los individuos ante la adversidad, sino en la necesidad de fomentar la virtud como fundamento de la convivencia social. El énfasis en lo espiritual no supone aquí una exhortación a cortar amarras con el mundo terrenal, sino -y aquí observamos la vocación programática del humanismo vivesiano con toda su intensidad- una llamada a organizar este mundo según la ley de lo espiritual.

Lo que encontramos en la Introductio ad sapientiam es, en definitiva, una Philosophia Christi, si bien Vives, al incluir en ella elementos estoicos, llegó más lejos que Erasmo en el camino hacia la autonomía de la filosofía moral. En cualquier caso, es importante señalar que Vives, al contrario que un Lipsio o un Sánchez de las Brozas, no hizo del estoicismo una filosofía moral propiamente autónoma. La Introductio ad sapientiam está plagada de referencias cristianas que no son meramente aledañas, sino que revisten importancia en la construcción teórica del tratado. No olvidemos que Vives definía el conocimiento de Dios como fin último de la sabiduría, y que define la virtud como «piedad para con Dios y para con los hombres» (\$18). Además, hay una serie de aforismos en la obra (\$§254-317) netamente religiosos y que vienen introducidos así:

\$254 Estas máximas que hemos dicho hasta ahora van dirigidas al hombre desde el hombre; ahora vamos a subir un poco más alto, es decir, vamos a decirlas desde Dios; aunque también aquellas son desde Dios. Pero las que vamos a decir, un poco más expresamente y más propiamente.

Aunque su proyecto de Philosophia Christi se desliga del marco teórico metafísico de la teología medieval y se constituye como una moral práctica de observancia individual, Vives no renuncia a armonizar la razón con la fe (una fe, en

\footnotetext{
${ }^{18}$ No hay que olvidar que todo esto tiene, a su vez, resonancias religiosas. La concordia ha de ser el resultado de la puesta en práctica de aquella exhortación lanzada por Cristo, «amarás al prójimo como a ti mismo». Así, en $\$ 402$ dice Vives: «Puesto que debes este amor a los hombres, piensa que nada te puede disponer mejor que procurándoles el máximo bien, esto es, la virtud; si te preocupas de hacer buenos a todos o al mayor número posible».
} 
todo caso, evangélica, libre de toda la carga teológica que los escolásticos habían puesto sobre sus hombros). Los humanistas, en cualquier caso, no tenían esa necesidad de separar esferas; en cierto modo, es posible que fuera la creciente intransigencia religiosa de las últimas décadas del siglo XVI la que propició un verdadero distanciamiento de los ámbitos de la razón y de la fe también en el campo de la moral, sentando así las bases para el surgimiento del neoestoicismo. Por otro lado, dicha intransigencia hizo también inviable el proyecto político y social de los humanistas; es fácil prever, en virtud de ello, que la moral estoica tomará a partir de aquí derroteros nuevos y adquirirá matices bastante distintos.

\section{2.- Estoicismo y Contrarreforma: de la sabiduría como juicio recto a la moral del desengaño}

\section{1.- La continuidad del erasmismo después de la Contrarreforma ${ }^{19}$}

Si de entre todas las naciones de Europa hubo alguna en la que el impacto de las obras y del pensamiento de Erasmo fue especialmente profundo - es más, hasta tal punto profundo que no sería exagerado afirmar que el erasmismo constituyó el elemento más importante de su vida espiritual durante al menos dos décadas - esa nación fue sin duda España.

Son diversos los factores que, a principios del siglo XVI, hacían de España el caldo de cultivo perfecto para las ideas reformistas erasmianas. Por un lado habría que tener en cuenta la sombra del cardenal Cisneros, a cuya influencia todavía viva en la década de 1520 podría atribuirse la predisposición por parte de importantes sectores de la Iglesia a tantear la necesidad de una reforma de la institución. En segundo lugar, no menos relevancia tuvo para semejante acogida de la piedad erasmiana en suelo peninsular la proliferación de sectas quietistas y alumbradas, cuyos miembros debieron encontrar en los libros del roterodamo una vía para la expresión y la defensa de sus propias posiciones en materia religiosa. Pero en cualquier caso, sería la presencia de una corte real que erasmizaba abiertamente, unida, por un lado, a la aprobación del Inquisidor General Manrique, y por otro al beneplácito expreso que el nuevo rey Carlos I otorgó a la publicación de las obras de

\footnotetext{
19 Para una exposición más pormenorizada de los acontecimientos históricos que aquí se reseñan, véase el prólogo de Marcel Bataillon a: ERASMO de Rótterdam, Desiderio: El Enquiridion o Manual del Caballero Cristiano y La Paráclesis o Exbortación al estudio de las letras divinas, Madrid, [s.n.], 1971.
} 
su compatriota lo que acabaría por dar un espaldarazo definitivo a la difusión del pensamiento de Erasmo en territorio español.

Si bien durante algunos años — mientras los hermanos Juan y Alfonso de Valdés forman parte de la corte del Emperador, y tienen lugar acontecimientos como el Saco de Roma, que pone en boca de todos la corrupción que corroía a la Iglesia católica de la época- pareció posible e incluso al alcance de la mano el triunfo y la implantación de la religiosidad erasmiana en España, semejantes ilusiones no tardarían en verse frustradas. El humanismo cristiano terminaría naufragando y, como en el resto de Europa, también en España su fracaso fue concomitante al aplastante éxito de la reforma luterana, que relegó las posiciones de Erasmo y sus seguidores a un peligroso terreno de nadie. Muy pronto los detractores del holandés percibieron esta flaqueza y emprendieron una campaña de denuncias a la Inquisición, acusando a los propios erasmistas (ya que contra los libros que éstos enarbolaban nada podían hacer) de incitar a la herejía luterana. Y la contraofensiva triunfó: Erasmo empezó a ser visto como un autor peligroso, y más aún a medida que la reforma se extendía por toda Europa y se incrementaba el temor a que España se viera contagiada por las nuevas ideas luteranas. Así pues, mientras el fervor erasmista decaía, sucesivas prohibiciones fueron poniendo a la obras del escritor holandés fuera de circulación. Si a partir de 1537 sólo era posible encontrar el Enchiridion en las librerías españolas, en 1559 éste acabaría también por ser prohibido. Cuatro años antes de que se estableciera la nueva ortodoxia en Trento, la vida editorial en España del llamado «Príncipe de los Humanistas» había llegado ya a su final definitivo; una obra como el Enchiridion, cuya traducción por parte del Arcediano del Alcor había sido lo que hoy prosaicamente llamaríamos un best-seller durante la década de 1520, apenas cuarenta años más tarde había desaparecido ya prácticamente de todas las estanterías de las bibliotecas españolas.

Sin embargo, la incidencia del pensamiento de Erasmo en la vida espiritual del país no fue tan volátil como para que, ausentes sus obras, se diluyera también su influencia. Como bien decía Marcel Bataillon: «Reinando Felipe II empieza una segunda fase del erasmismo español, la del erasmismo sin Erasmo» ${ }^{20}$. Un erasmismo que buscaría nuevas formas de expresión, obligado a reinventarse ante las nuevas

${ }^{20}$ Cfr. El Enquiridion o Manual del Caballero Cristiano y La Paráclesis o Exhortación al estudio de las letras divinas, ed. cit., prólogo, 84. 
circunstancias y los nuevos problemas que se le presentaban, y que, ciertamente, terminaría por diluirse en el seno de la nueva ortodoxia, pero al que no obstante aguardaba todavía un largo recorrido. No deja de ser cierto, en todo caso, que el humanismo cristiano en sentido estricto, es decir, tomado con sus connotaciones programáticas educativas o religiosas, dio por terminada aquí mismo su andadura, siendo lo que vino después, aunque fuera tan sólo porque las circunstancias así lo imponían, algo bastante distinto. Como hemos afirmado más arriba, el triunfo de la Reforma y esa contundente respuesta que fue la Contrarreforma fueron los dos acontecimientos paralelos que sentenciaron a muerte al humanismo como proyecto religioso, social y político. El optimismo y la confianza en la dignidad humana indispensables para el sostenimiento de un programa semejante se perderán irrevocablemente en este momento de inflexión, a partir del cual reaparecerá con fuerza el tópico de la miseria hominis y serán una constante las exhortaciones al desprecio del mundo terreno y al retiro espiritual. Con todo, intentar comprender la historia intelectual del primer siglo de Contrarreforma sería una tarea imposible si despreciásemos la importancia de aquellos elementos propiamente erasmistas que sobrevivieron después de Trento y que lograron adaptarse (aunque no se libraran de importantes encontronazos con la Inquisición) a la nueva atmósfera intelectual.

Un primer ejemplo de la penetración del erasmismo en el mundo de la Contrarreforma lo encontraríamos en el gran florecimiento de la teología y la literatura mística a finales del siglo XVI en España. Es fácil observar cómo entre la filología bíblica y patrística practicada por Erasmo durante gran parte de su vida y la trayectoria intelectual de un Fray Luis de León existen paralelismos más que notorios. Pero también funcionó la ética estoica como catalizador de algunas de las inquietudes humanistas que lograron pervivir durante aquellos años ${ }^{21}$. A este respecto es de destacar la figura del humanista extremeño Francisco Sánchez de las Brozas, conocido como el Brocense.

\section{2.- Importancia de la doctrina del estoico filósofo epicteto que se llama} comúnmente enchiridión (1600), de Francisco Sánchez de las Brozas

\footnotetext{
${ }^{21}$ Sin embargo, el papel del estoicismo en esta época no deja de ser complejo y ambivalente, pues también tuvo su importancia en la consolidación de la moral más ortodoxamente contrarreformista. Cfr. BLÜHER, Séneca en España, op. cit., 340 y ss.
} 
Don Francisco Sánchez de las Brozas (1523-1600) fue catedrático de retórica y griego en la Universidad de Salamanca, y desde tan privilegiada posición defendió las últimas plazas del humanismo en España. En su magisterio universitario y en obras como el De nonnullis Porphyrii aliorumque in Dialectica erroribus scholae Dialecticae, que le granjearon fama y renombre en toda Europa, el Brocense puso todo su empeño en minar los cimientos de la teología, la lógica y la ciencia establecida, practicando una crítica radical que rebasaba con creces los límites ordinarios del erasmismo. Lejos de limitarse a amonestar la hipocresía de la religión externa o la vanidad de la teología de las escuelas, a clamar por una vuelta a la sencillez y el fervor de la religión de los orígenes o a buscar un modelo de educación que verdaderamente instruyese en la virtud, el implacable espíritu crítico de Sánchez de las Brozas le llevó a arremeter directamente contra los dos grandes pilares del que era y había sido el edificio del saber durante siglos: la lógica escolástica y el principio de autoridad. Pero lo verdaderamente novedoso no era tanto el alcance como el lugar desde el que se producía el ataque: un racionalismo crítico y un escepticismo atento que buscan evidencia antes de conceder asentimiento, y que sólo allí donde no la encuentran se encomiendan a la fe. Supone esto, en cierta medida, la culminación del camino abierto por el erasmismo: la crítica a la razón dialéctica de la teología, al ejercerse desde la defensa firme de la libertad intelectual del individuo, sienta las bases de una nueva razón individual, autónoma y crítica, que al alcanzar su consolidación será la que lleve el desmontaje de la teología hasta sus últimas consecuencias. En Erasmo, un fideísmo evangélico se oponía a la autoridad de la razón teológica; en el Brocense, la razón, independiente, crítica, se opone a la autoridad.

La nueva España contrarreformista no podía dejar de ver las ideas de Sánchez de las Brozas como un grave peligro para la ortodoxia, tanto más cuanto que el extremeño ejercía un magisterio público. Y en efecto, el Brocense tuvo que sufrir varios procesos inquisitoriales a lo largo de su vida, el último de los cuales, abierto en 1593, concluyó con su arresto domiciliario y la confiscación de todos sus escritos. Finalmente, las últimas plazas del humanismo en España habían sido sitiadas, y Sánchez de las Brozas, su último defensor, tuvo que refugiarse en el único baluarte que le quedaba —el mismo al que Fray Luis de León había ido a buscar 
cobijo: el retiro, la renuncia, el abandono del mundanal ruido. Sólo que mientras el monje agustino cantaba al retiro geográfico, el Brocense decidió ensayar la vía del retiro puramente espiritual, para lo cual se sirvió de la filosofía estoica de Epicteto. De este modo, ya anciano y totalmente apartado de la vida pública, el antiguo profesor de griego emprendió la traducción y el comentario en español ${ }^{22}$ del Encheiridion de Epicteto, que vería la luz en 1600 — siete años después de su redacción y ya de manera póstuma- bajo el título de Doctrina del estoico filósofo Epicteto, que se llama comúnmente Enchiridión.

La adhesión del Brocense a la ética estoica entronca en gran medida con el recurso a la misma que ya ensayara Vives, y por tanto con el ideario humanista. La primera muestra de esto lo encontramos en el prólogo, donde Sánchez de las Brozas examina las doctrinas sobre la virtud de los filósofos antiguos y lanza contra los peripatéticos las mismas críticas que el valenciano vertía en su De disciplinis: «Io digo que la doctrina de Aristóteles no enseña cómo se pueda conseguir <la virtud>», dice el Brocense ${ }^{23}$. «Lo primero, porque él mismo confiesa que es gran dificultad poder acertar con la virtud, por estar tan secreta entre dos vicios. Lo segundo, porque él no da regla para hallarla [...]. Lo tercero, porque él mismo dize que este medio entre dos vicios no lo entendamos que sea mathemático i medido en devida i justa proporción [...]. Lo quarto, porque dize en otra parte que para la felicidad son menester poderes, autoridad de personas i bienes corporales. Lo quinto, porque hablando de aorgesia, que es el no enojarse, llama tonto i sin juizio al que no se enoja cuando i como conviene» ${ }^{24}$. En todo esto, aunque no se le nombre, resuena vivamente la voz de Vives, y en la conclusión final del argumento oímos aún la voz de Erasmo: «Los propios i verdaderos contrarios de las virtudes son aquellos que tienen gran semejança $i$ parentesco con la misma virtud $i$ an de estar entrambos debajo de un mismo género [...]. Ansí que el contrario de religioso es el hipócrita, no el hereje». 25

\footnotetext{
22 Es de reseñar que el uso de la lengua vernácula para la redacción de un escrito sobre moral era, en la época, una actitud muy denotadamente erasmista.

${ }^{23}$ Francisco SÁNCHEZ DE LAS BROZAS, Doctrina del estoico filósofo Epicteto, que se llama comúnmente Enchiridión, Badajoz, Departamento de publicaciones de la Diputación de Badajoz, 1993, Prólogo, 101.

${ }^{24}$ Ibid., 102.

25 Ibid., 103.
} 
En definitiva: como Vives, el Brocense encuentra en el estoicismo una ética que se puede sostener desde la pura subjetividad, sin necesidad de una fundamentación metafísica a la que un temperamento escéptico como el suyo es incapaz de adscribirse. A este respecto, la originalidad del Brocense, aquello en lo que rebasaría a Vives, consistiría en haber despojado a la moral de todo resto de fideísmo. El hecho de que no se decidiese por escribir un manual de moral propio, sino que optase por traducir y comentar el que ya escribió Epicteto, vendría a confirmarnos este extremo: por un lado, pone de manifiesto que Sánchez de las Brozas no se limitó a tomar elementos estoicos y elaborar, a partir de ellos, una síntesis con la moral cristiana, sino que prefirió adherirse al estoicismo como moral válida en sí misma ${ }^{26}$; por otro lado, la elección específica de Epicteto y no de otros autores estoicos pone de relieve su voluntad de adoptar una versión del estoicismo especialmente sistemática y racionalizada. No olvidemos que Epicteto parte, ya desde los primeros compases de su Encheiridion, de una distinción tajante entre lo que pertenece al ámbito de la libertad del hombre y lo que está totalmente fuera de su alcance ${ }^{27}$ : a este segundo terreno pertenecerían el cuerpo y los bienes exteriores, mientras que el primer ámbito quedaría reducido exclusivamente a lo anímico y espiritual —dicho en cristiano: al alma. Este punto de partida permitirá al Brocense propugnar una completa autonomía para la decisión moral; como ya sucedía con Vives, el hombre es concebido como capaz de decidir libremente su valoración de las cosas externas, y Sánchez de las Brozas repetirá justamente la misma definición de la sabiduría que defendía el valenciano: «la verdadera sapiencia es no errar i dar a cada cosa su valor» ${ }^{28}$.

\footnotetext{
${ }^{26}$ A este respecto, resulta significativo que la única crítica dirigida a Epicteto por parte del Brocense se refiera al hecho de que hable de «dioses» en plural (Cfr., Francisco SÁNCHEZ DE LAS BROZAS, Doctrina del estoico filósofo Epicteto..., op. cit., 104). Reprochará también a los estoicos en general que «fueron mui rígidos y ásperos (Cfr., Ibid., 101) y que su búsqueda de la virtud, sin la fe infusa, es insostenible. Sin embargo, ningún reparo pone, como veremos más adelante, a su doctrina del fatum o a la prescripción que Epicteto hace en el capítulo 18 de que se finja la condolencia por las desgracias ajenas (Cfr., Ibid., 153).

${ }^{27}$ Acaso haya que señalar que el Encheiridion - obra que no redactó el propio Epicteto, sino uno de sus discípulos- está dividido en aforismos o parágrafos, algunos de los cuales están, a su vez, divididos en secciones. Esta tesis fundamental se halla expresada en las dos primeras secciones del primer parágrafo del Encheiridion (I, 1-2), que se corresponden, en la versión del Brocense, con el primer capítulo (Cfr., Francisco SÁNCHEZ DE LAS BROZAS, Doctrina del estoico filósofo Epicteto..., op. cit., 109).

${ }^{28}$ Francisco SÁNCHEZ DE LAS BROZAS, Doctrina del estoico filósofo Epicteto..., op. cit., 127.
} 
Con estos breves trazos, queda claro que las afinidades ideológicas del Brocense con el humanismo precedente no se han diluido a pesar de las nuevas circunstancias en que desarrolla el extremeño su labor intelectual. Quizás donde este vínculo se vea expresado más claramente es en los comentarios a los capítulos 51, 52, 53 y 54, donde el Brocense evoca la polémica humanista con la escolástica al criticar el saber y la erudición que, permaneciendo en la ostentación, no redundan en ninguna utilidad práctica ${ }^{29}$.

Sin embargo, aunque el estoicismo del Brocense y el de Vives sean equiparables por el lado de su común humanismo, lo cierto es que las razones últimas del extremeño para adherirse a la doctrina de la Stoa son bastante distintas de las que podría haber albergado el valenciano. Ya comentamos cómo la ética de Vives se inscribe en un ambicioso programa social y político. En su horizonte estaba la renovación moral del hombre. El Brocense, por el contrario, sólo tiene por horizonte la defensa de su propia autonomía moral frente a las potestades exteriores. Atosigado por la Contrarreforma, el humanismo pierde toda confianza en el cumplimiento de sus programas, y sus ideas en materia moral se ven relegadas a la salvaguarda de lo privado. Ahora bien, la salvaguarda que el estoicismo de Epicteto otorga a la autonomía moral del individuo no consiste en otra cosa que en enseñarle que sólo su disposición acerca del valor de las cosas está verdaderamente en su mano, y que por tanto permanecerá libre en la medida en que sea capaz de aceptar los acontecimientos que no dependen de él tal y como le vengan, de manera impasible y sumisa. Igual que Lipsio, Sánchez de las Brozas aceptará la doctrina estoica del fatum y - reinterpretándolo como hado de la providencia divina ${ }^{30}$ localizará en el aprendizaje de la aceptación de sus designios uno de los réditos más importantes de las enseñanzas de Epicteto.

\footnotetext{
${ }^{29}$ Resulta ciertamente llamativa la traducción del texto de Epicteto que el Brocense ofrece en el capítulo 54, más concretamente en lo relativo a este pasaje:

Si alguno, porque entiende i explica los libros de Crisipo o de Aristóteles, tiene gravedad o fantasía, di tú entre ti: "Si Aristóteles no escribiera obscuro, no tuviera éste gravedad i arrogancia..." (220).
}

En el original griego no aparece alusión alguna a Aristóteles. Que Sánchez de las Brozas incluyera aquí su nombre, instrumentalizando el pasaje con fines polémicos, da cuenta de la intensidad de la confrontación del extremeño con el escolasticismo.

${ }^{30}$ Cfr., Francisco SÁNCHEZ DE LAS BROZAS, Doctrina del estoico filósofo Epicteto..., op. cit., cap. 60: La vida no es nuestra, la voluntad es nuestra, i ésta se debe siempre emplear en Dios (228). 
En consonancia con esta insistencia en la sumisión a la providencia, hallamos en el Brocense la recuperación de una imagen muy típica en los estoicos y que, en gran medida a través de ellos — de Epicteto y, de manera mucho más decisiva, de Séneca- se transmite al Barroco y se convierte en un tópico altamente representativo del sentir de la época: a saber, la imagen del mundo y de la vida como un teatro en el que Dios reparte los papeles y cada cual debe contentarse con aquel que le ha tocado representar ${ }^{31}$. Se trata de un símbolo estrechamente vinculado a una cierta actitud de desprecio hacia la vanidad de todo lo terrenal: si estos distintos «papeles» que representamos en la escena del mundo se reducen, en definitiva, a honores, cargos, bienes externos, etc., ¿qué importancia pueden tener, dado que tales cosas se hallan fuera de la mano del hombre? Otra idea vuelve a despuntar aquí con fuerza: que todo en esta vida es prestado, y nada nuestro ${ }^{32}$.

Todas estas ideas habría que ponerlas en relación con el escepticismo cognoscitivo que (volvemos a reiterar) fue una constante en la época y que Sánchez de las Brozas también sostuvo hasta cierto punto. Karl Blüher señala cómo, en su traducción del Encheiridion, el Brocense toma a veces decisiones que pueden interpretarse fácilmente como fruto de una lectura escéptica de la filosofía de Epicteto $^{33}$ - lectura que, si en el propio autor extremeño se hallara mitigada, Quevedo acabaría no obstante llevando hasta sus últimas consecuencias al elaborar su propia traducción en verso del Encheiridion. Así, por ejemplo, el término

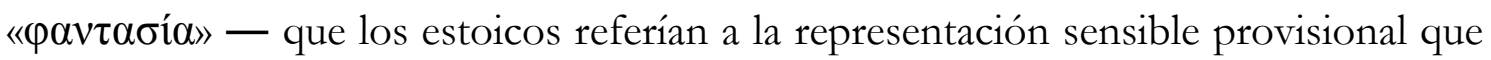
se apodera de la mente humana, a la espera de que el juicio le otorgue su asentimiento y le confiera así valor de verdad, transformándola en $\varphi \alpha v \tau \alpha \sigma i ́ \alpha$

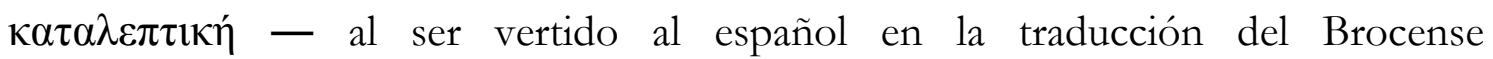
alternativamente como «fantasía», «imaginación»y «fantasma» ${ }^{34}$, se reviste de los ropajes de lo puramente aparente, sin remisión a la verdad. El papel del juicio se verá de esta manera transfigurado, y con ello quedará trastocada toda la utilidad del estoicismo como moral práctica. Si en Vives juzgar era otorgar y denegar valor a las cosas, apreciarlas a todas en su justo precio y por su provecho relativo a la

\footnotetext{
31 Cfr., Ibid., cap. 19: La vida es una comedia i Dios, el que da los personages i los dichos (155).

32 Cfr., Ibid., cap. 13: Nadie pierde nada: restituimos a Dios lo que nos dio (143).

33 Cfr., Karl Alfred BLÜHER, Séneca en España, op. cit., 377-381.

${ }^{34}$ Cfr. Francisco SÁNCHEZ DE LAS BROZAS, 123.
} 
consecución de la virtud, en la lectura del Brocense el juicio, al aplicarse sobre las cosas externas, no tendrá otra función que la de desenmascararlas, denegándoles todo valor. El estoicismo se convertirá así, a partir de aquí y en todo el Barroco, en una moral del desengaño, que enseña que la vida es un sueño, una comedia en la que no elegimos nuestra parte, pero no nos queda más remedio que aceptarla; y que, dicho en castizo, hay que «cargar con lo puesto y poco más».

En el Brocense el estoicismo es una armadura, una fortaleza en la que la razón puede hallar resguardo. Su obra, en cierto sentido, marca un punto de inflexión en la recepción del pensamiento estoico en España, pues si bien siguen quedando en ella vínculos claros con el humanismo pretridentino, también empiezan a vislumbrarse en sus páginas los caminos por los que habrá de transitar el neoestoicismo del siglo XVII. Impregnada por un cierto aroma de desilusión y resignación, la Doctrina del estoico filósofo Epicteto marcará el fin del humanismo en España, pero también constituirá la válvula por la cual los últimos restos del erasmismo, cierto que ya bastante mitigados, se transfieran al Barroco, transfigurándose el humanismo en neoestoicismo cristiano.

\section{3.- El Neoestoicismo Barroco de Francisco de Quevedo: La cuna y la Sepultura (1633)}

El neoestoicismo español del siglo XVII tiene como representante más eminente al escritor y poeta madrileño Francisco de Quevedo y Villegas (15801645). Su adhesión a la filosofía estoica, posiblemente inseparable de sus torpes intentos de enmendar una biografía bastante tortuosa, nos remite en todo caso a tres fuentes principales. La primera de ellas es la propia obra de Sánchez de las Brozas, que Quevedo encomió y de la que se sirvió para su propia traducción en verso del Encheiridion de Epicteto ${ }^{35}$. En segundo lugar, se sabe que Quevedo bebió también del neoestoicismo de Lipsio, con quien además mantuvo una asidua correspondencia durante los últimos años de vida del maestro holandés. Por último, habría que citar la influencia que ejerció sobre el poeta madrileño la literatura sermocinal que empezó a proliferar desde las últimas décadas del siglo XVI y que en

${ }^{35}$ Esta traducción está recogida como apéndice en EPICTETO, Enquiridion, Barcelona, Anthropos, 1991. 
sus prédicas hacía uso constante de tópicos estoicos extraídos fundamentalmente de las obras de Séneca ${ }^{36}$.

Aparte de sus traducciones versificadas de Epicteto y del Pseudo-Folcílides, fueron varias las obras morales que publicó Quevedo y que nos llevan a catalogarlo como autor neoestoico. Aquí nos interesará tan sólo el tratado titulado La cuna y la sepultura. Editada en 1633, este libro es la refundición de un texto anterior del autor que se publicó sin su consentimiento en 1630 bajo el título de Doctrina moral. Los cinco capítulos que componían esta primera versión, corregidos y modificados, conformarían posteriormente la primera parte de La cuna y la sepultura, «Cuna y vida». A ellos añadirá Quevedo, como epílogo, una «Doctrina para morir», encabezada por el rótulo «Muerte y sepultura».

La cuna y la sepultura - cuyo subtítulo reza «Para el conocimiento propio y desengaño de las cosas ajenas» - presenta la doctrina estoica como una moral de desengaño. Quevedo entiende que el sabio estoico es el que sabe dirigir su juicio rectamente y otorgar a todas las cosas su justo valor, estando así en perfecta disposición para elegir lo bueno en vez de lo malo. Ahora bien, mediante el buen juicio aprendemos que lo único digno de ser valorado es la virtud, y que todo lo demás nada vale, pues además no nos pertenece y no podemos adueñarnos de ello sino temporal y pasajeramente. Es por esta razón que se hace necesario que nos «desengañemos» de las cosas ajenas y nos centremos en conocer y cultivar aquello que nos es propio, que es la virtud de nuestra alma. Esta idea — que encuentra su raíz en la deriva escéptica que el Brocense y Lipsio imprimieron en el estoicismo y distingue el de Quevedo de otros intentos previos de acercamiento del cristianismo a la Stoa como el que ya hemos estudiado de Vives- constituye el núcleo

\footnotetext{
${ }^{36}$ Los autores de este tipo de literatura religiosa, a diferencia de los neoestoicos, supeditaron siempre su interés por el estoicismo a las labores de la predicación. Dicho de otra manera, lo que les interesaba no era la doctrina moral estoica en sí, sino tan sólo en la medida en que podía ser útil a la teología. Con todo, y siendo Quevedo un autor neoestoico, la influencia que estos autores ejercieron sobre él no se puede desdeñar, sobre todo si tenemos en cuenta que fueron ellos los primeros en hacer hincapié en aquellos tópicos estoicos relacionados con la miseria bominis que luego tan importantes serán en obras como La cuna y la sepultura: la vida como préstamo, el carácter pasajero de todos los bienes exteriores, la brevedad de la existencia terrena, el absoluto sometimiento del hombre a las calamidades que le depara el destino... Fueron, en definitiva, predicadores como Juan de Mariana, Pedro de Rivadeneira o Luis de Granada los que allanaron el terreno para el aprovechamiento del estoicismo durante el siglo XVII en un sentido propiamente Barroco. Para más detalles al respecto, véase BLÚHER, Séneca en España, op. cit., 340-361.
} 
ideológico de toda la obra y es el motor de la argumentación que en ella se despliega y que intentaremos resumir en estas últimas páginas.

A lo largo del tratado, Quevedo pondrá continuamente el énfasis — cosa que también separa irremediablemente sus tesis de las del humanismo- en la miseria de la vida humana, pues la toma de conciencia de ésta es justamente la que sirve como catalizador del desengaño: ya desde la primera página del proemio vemos entrar en juego el tópico estoico del cotidie morimur ${ }^{37}$, y a renglón seguido se señalará la importancia de la concepción, también estoica, de la vida como préstamo ${ }^{38}$. Donde sí podemos observar, en cambio, un residuo de las actitudes del humanismo que permanece en el neoestoicismo es en la justificación que Quevedo ofrece de su recurso a la moral de la Stoa: apela a ella, según afirma, porque se sostiene por la razón y sin necesidad de apelar a la autoridad ${ }^{39}$. Su carácter autónomo, por tanto, cuenta para el poeta como una ventaja.

Reminiscente de las obras que ya hemos abordado es también el primer capítulo de «Cuna y vida», pues Quevedo pone también el punto de partida en el imperativo socrático: sólo a partir del «conocimiento propio» se hará posible el «desengaño de las cosas ajenas». El texto empieza presentando al hombre según la tradicional división bipartita cristiana: el hombre consiste en cuerpo y alma, y al venir al mundo se le encarga al cuerpo vivir y sustentar la vida y al alma buscar la buena vida.

Quevedo señala la necesidad de valorar correctamente todas las cosas, y que con respecto al cuerpo y al alma la valoración correcta es aquella según la cual el alma es la parte más importante del hombre, mientras que el cuerpo es tan sólo su sustento o, más bien, un instrumento, un esclavo y un criado del alma. Entrará aquí en juego, nuevamente, el tópico de la miseria hominis, la devaluación de la vida terrena a través de una serie de imágenes que Quevedo desplegará con el fin de reforzar esta valoración inicial. Siguiendo el intelectualismo estoico, el poeta madrileño considera que la miseria del hombre tiene su fruto, en última instancia, en una valoración

\footnotetext{
${ }^{37}$ Cfr., Francisco de QUEVEDO, La cuna y la sepultura, Madrid, Cátedra, 2008, Proemio, 65.

${ }^{38}$ Cfr., Ibid., 67.

${ }^{39}$ Cfr., Ibid., 67.
} 
errónea del alma y el cuerpo, en virtud de la cual se pone a éste último por encima de aquélla. Así, ya a esta primera tarea del conocimiento propio es correlativa una labor de desengaño: hemos de desengañarnos con respecto al valor de nuestro cuerpo, verdadero «sepulcro del alma», y aprender que el alma es la parte más preciosa del hombre: sólo a partir de aquí podrán valorarse rectamente las demás cosas.

Esto último, la valoración de las cosas ajenas, empieza a recibir tratamiento en el segundo capítulo de la obra. Una vez ganado el conocimiento de sí, Quevedo nos insta a la ordenación de las potencias del alma, que agustinianamente concibe que son tres: «entendimiento, memoria y voluntad $»^{40}$. El fin es que el propio tribunal del alma decida rectamente acerca de los objetos a los que su voluntad puede dirigirse de manera legítima. Se descubre enseguida que, según indicación de la razón natural, sólo Dios debe ser amado, pues Él es lo único que de por sí es amable. Sin embargo, no siempre amamos a aquello que racionalmente deberíamos amar, sino que a veces caemos en la concupiscencia y deseamos poder, riquezas, una gran mansión o a una mujer atractiva. Todos estos deseos asevera Quevedo que son fruto de un mal uso de nuestro entendimiento que repercute negativamente en nuestra voluntad y nos hace caer en la miseria. Hace falta, por tanto, que el entendimiento se desengañe para que la voluntad se libere de semejante sumisión. Todo pasa, en definitiva, por un cambio de mirada.

Si bien la formulación quevediana del problema moral toma pie en la división agustiniana de las facultades del alma, vemos claramente cómo la solución que propone es netamente estoica, y está regida por la doctrina de los afectos propia de los filósofos del pórtico: los afectos se apoyan en la apreciación que nuestro juicio (en Quevedo, siguiendo su terminología agustiniana, deberíamos hablar de «entendimiento») hace de las cosas. Luego toda corrección de los afectos habrá de pasar por una revisión de nuestro juicio.

Pero lo más destacable en la doctrina del juicio y de los afectos quevediana es el acento puesto en la noción de «desengaño» — noción que, como ya apuntamos al hablar del Brocense, tiene su origen en la propia lógica estoica del juicio, en la medida en que el desengaño consiste, en La cuna y la sepultura, en un juicio por el que

${ }^{40}$ Cfr., Ibid., 83. 
consideramos errónea toda la atribución de valor que previamente le habíamos concedido a algo. La moral de Quevedo es, como toda moral estoica, una moral de la virtud y la vida interior, pero se trata ante todo de una doctrina del desengaño y una doctrina desengañada. Nos enseña que todas nuestras tribulaciones nacen de nuestra falsa apreciación de las cosas. Pero si algo le interesa a Quevedo no es otra cosa que señalar cuán falsa es nuestra apreciación y disuadirnos enérgicamente de ella.

En el segundo capítulo Quevedo aplica esta doctrina del desengaño exclusivamente a aquellas cosas que generan en nosotros afecciones concupiscentes; en el tercero, su atención se centra en aquello que nos genera angustia, y muy especialmente en la muerte ${ }^{41}$ y en la ira. Pero será en el cuarto capítulo donde este pathos desengañado alcance su máxima expresión, en la medida en que Quevedo lanza la sombra de la duda sobre aquello en lo que se cifra la más grande soberbia de los hombres: el conocimiento.

Asevera Quevedo que en la sabiduría reside mayor hipocresía que en la riqueza o en el valor; porque en el valeroso hay valor, en el rico hay riquezas que lo atestiguan, pero en el que se autoproclama sabio no hay en verdad sabiduría alguna, sino nada más que presunción y vanidad. El desengaño es aquí, por esto mismo, tarea mucho más difícil.

Se acumulan aquí todos los tópicos escépticos quevedianos: «la sabiduría verdadera está en la verdad, y la verdad es una sola, y esa verdad una es Dios solo, que por eso le llaman Dios verdadero; y fuera dÉl todo es opinión, y los más cuerdos sospechan» ${ }^{42}$. El mundo terrenal es, pues, el mundo de la opinión, de lo aparente e ilusorio, siendo así que sólo empieza a adquirirse verdad después de la muerte, una vez el alma se ha despojado de las ataduras del cuerpo y comienza su camino hacia Dios.

Quevedo rechaza que haya habido jamás sabios sobre la tierra, apoyándose en que ellos mismos se dieron en verdad el nombre de «filósofos» (amantes de la sabiduría, y no sabios) y a lo largo de la historia se han ido refutando los unos a los

41 Es de destacar la omnipresencia del tema de la muerte en La cuna y la sepultura, en la medida en que contrasta con la práctica ausencia de alusiones a ella en la Introductio ad Sapientiam de Vives. En virtud de ello, podríamos destacar esta omnipresencia como uno de los rasgos distintivos del neoestoicismo barroco quevediano.

42 Francisco de QUEVEDO, La cuna y la sepultura, Madrid, Cátedra, 2008, Proemio, 113. 
otros, siendo así que Sócrates — acaso el menos hipócrita- confesaba además no saber nada.

Pero todo esto no es óbice para que el hombre no tenga algo que aprender: «No me parece que el trabajo y el estudio del hombre se logrará en nada fuera de la consideración y ejercicio de las virtudes, que es sólo lo que a un hombre pertenece. Procurar persuadirte a amar la muerte, a despreciar la vida, a conocer tu flaqueza y la vanidad de las cosas que, fuera de aquel solo Señor, son, pues sólo el buen uso de todas, ordenado a aquel fin, está a tu cargo» ${ }^{43}$. Aquí se cifraría lo que Quevedo está intentando promover en La cuna y la sepultura: un cultivo interior que parapete al alma contra todas las insolencias de la fortuna y contra todo aquello que, dentro de ella misma, pueda llegar a perturbarla.

Desde estas coordenadas Quevedo lanza un último ataque contra toda presunción de saber en torno a los movimientos de los astros, a la generación y corrupción y demás cosas de que han venido ocupándose los filósofos desde antiguo: más allá de las legítimas dudas acerca de si es posible en ellas llegar a la verdad o no podemos pasar de la mera opinión, todas esas cosas no sirven más que a la disputación, pero ninguna utilidad real tienen para la vida humana.

Resuenan, en esta crítica farisaica a la hipocresía de los eruditos escolásticos, unos últimos ecos erasmistas ${ }^{44}$, escondidos bajo el polvo de la defensa a ultranza, más que del escepticismo crítico que arreció durante los últimos estertores del humanismo (y del que el Brocense constituía un caso paradigmático), de una piadosa y docta ignorancia, perfectamente integrada ya en las coordenadas espirituales de la Contrarreforma. Y Quevedo nos dice muy claramente qué es lo que realmente importa: «Acaba de persuadirte a que dentro de ti mismo tienes que hacer tanto que, aun por larga que sea tu vida, te faltará tempo; y que no puedes saber nada bueno para ti, si no fuere lo que aprendieres del desengaño y de la verdad; y que entonces empezarás a ser sabio, cuando no temieres las miserias ni codiciares las honras ni te admirares de nada y tú mismo estudiares en ti, que leyéndote está tu naturaleza

43 Ibid., 115-116.

44 En el quinto capítulo de La cuna y la sepultura, que no comentamos aquí por ser ajeno a las tesis estoicas que pueblan los cuatro capítulos precedentes, estas resonancias erasmistas se hacen si cabe más manifiestas, pues Quevedo critica directamente la religiosidad basada en el culto externo. Además, según parece, Quevedo transcribe allí párrafos completos de un sermón del erasmista Constantino Ponce de la Fuente (Cfr., Antonio ALATORRE, «Quevedo, Erasmo y el Doctor Constantino», Nueva Revista de Filología Hispánica, VII (1953), 673-685.) 
introducciones de la verdad ${ }^{45}$. Conocimiento propio y desengaño de las cosas ajenas.

${ }^{45}$ Ibid., 118. 